Open Access

Res. Agric. Livest. Fish.

Research Article

Vol. 2, No. 1, April 2015: 135-141

\title{
SEASONAL ASSESSMENT OF EXISTING MUD CRAB (Scylla sp.) FATTENING PRACTICE IN BANGLADESH
}

\section{Zannatul Ferdoushi}

Associate Professor, Department of Fisheries Management, Faculty of Fisheries, Hajee Mohammad Danesh Science and Technology University, Dinajpur, Bangladesh

*Corresponding author: Zannatul Ferdoushi; E-mail: zannatul99bd@yahoo.com

\section{ARTICLE INFO ABSTRACT}

$\begin{array}{ll}\begin{array}{l}\text { Received } \\ 27.01 .2015\end{array} & \begin{array}{l}\text { The present study was conducted in the southwest part of Bangladesh from } 2008 \text { to } \\ 2009 \text { in order to assess of mud crab fattening practice and its production } \\ \text { performance between two different seasons. Generally two crab fattening seasons }\end{array} \\ \text { accepted } & \begin{array}{l}\text { are observed in Bangladesh, one is the dry or peak season (October to May) and } \\ \text { another one is lean season or wet season (J une to September). Significant variation } \\ \text { in stocking density was observed between two seasons during the study period. }\end{array} \\ \text { Online } & \text { Comparatively higher stocking density and higher production was found in dry season } \\ \text { 19.04.2015 } & \text { in comparison to wet season. The reasons behind higher production and production } \\ \text { Key words } & \text { rate were; the availability of the crabs and high market price for the crabs during dry } \\ \text { Production } & \text { season. On the other hand, rain fall, occurrence of diseases and natural disaster } \\ \text { Scylla serrate } & \text { might be the cause of lower production of crab during wet season. Crab farming and } \\ \text { Fattening } & \text { fishery could play a sustainable alternative employment opportunity for the } \\ \text { Mud crab } & \text { development of coastal people. So government should take some necessary steps for } \\ & \text { the development of this fishery. }\end{array}$

To cite this article: Ferdoushi Z. 2015. Seasonal assessment of existing mud crab (Scylla sp.) fattening practice in Bangladesh. Res. Agric. Livest. Fish. 2 (1): 135-141. 


\section{INTRUDUCTION}

Among all of the highly valued luxury foods, crustacean play an important role both in economically and environmentally. Scylla spp. commonly known as mud crab is now the most commercially important species and is widely distributed in the Indo-Pacific region, including the Bay of Bengal. Keenan et al., (1998) identified four distinct species S. serrata, S. tranquebarica, S. olivacea and S. paramamosain, among which S. serrata is more abundant in high saline water (Heasman and Fielder 1983). Because of their large size S. serrata fetch the highest market price of the four species in Eastern markets (Agbayani 2001).

Bangladesh has extremely favourable conditions for shrimp and crab culture. Decreasing the shrimp market price leads to an upsurge of interest in crab culture in Bangladesh (Khan and Alam, 1992).Fatteners are more interested in extending their farming due to its economic value in domestic and international market. Different types of crab aquaculture are practicing throughout the world including fattening, soft-shell and growout, while in Bangladesh crab fatteners mostly involved in fattening of lean or empty mud crab. Though crab culture is in its initial stage and there is considerable potential for further expansion thus it can be a new source of income generation in the southwest part of Bangladesh. According to Salam and Ross, (2000) there is potentialities in the coastal region of Bangladesh for establishing hatcheries to provide a continuous supply of crab seed.

However, researchers mostly concern on crab species identification and their distribution in Bangladesh. There is lack of research works about the fattening practice conducted by the fatteners in Bangladesh regarding the seasons. Generally, two crab fattening seasons so far have been identified in Bangladesh, one is dry or peck season (October to May) and another one is lean season or wet season (June to September). Based on these two seasons a comparative study on production performance was done by this research work. The study was under to observe the current fattening system and to assess the difference in production and management strategies involved in mud crab fattening between dry and wet season in the southwest part of Bangladesh.

\section{MATERIALS AND METHODS}

\section{Study area}

The Southwest part of Bangladesh; Khulna, Bagrhat and Satkhira; three districts were selected for this study. Three selected study areas are nearer to Sundarbon mangrove region which is the main source of crab fry for this culture practice.

\section{Data collection method}

A combination of following survey technique was used for data collection.

\section{Primary data collection Questionnaire Interviews}

Simple random sampling method with the key informants (School teachers, relevant NGOs, Department of Fisheries staffs in the field level) was followed for this research for questionnaire interviews. A total number of $150 \mathrm{crab}$ fatteners, 50 for each district were selected and were interviewed throughout the period of study. The interviews were focused on current fattening practice with its production. Fatteners were interviewed on their farms site in both dry and wet period during their production time.

\section{Secondary data collection}

Secondary data based on information collected from some published reports, papers and some official documents and reviews the existing information on the different aspects of the crab fattening in Bangladesh.

\section{Data processing and Analysis}

At each stage of survey, data were checked up, editing, and coding at the field level. Data from various sources were coded and enter into database system using SPSS (Statistical Package for Social Science) software. Preliminary data sheet were compared with the original coding sheets to ensure the accuracy of the data entered. Descriptive methods of analysis were used to describe the survey results using means and percentage. Some diagrams were also used for describing the findings. 


\section{RESULT}

\section{Pond size and design}

Usually all ponds were divided into several parts with bamboo fences and were also found to cover by mosquito net to prevent the crabs to escape. The average sizes of the ponds by area for crab fattening are showing in Table 1. The current study showed that about $41 \%$ ponds operated by the fatteners were small in size less than 0.05 ha. The average pond size among the three areas did not vary significantly $(P>0.05)$. The highest maximum size was found in Satkhira district followed by Bagerhat and Khulna.

\section{Water Level}

The water level during dry and wet season varied significantly among three areas $(P$ value $<0.05)$. The average water level during dry season in three study area was about $0.65 \pm 0.27$ meter with a range of 0.23 to 1.57 meter. On the other hand, the average water level during the wet season was about $1.29 \pm 0.30$ meter (Table 2).

\section{Source of crab seed}

Fatteners usually stocked the eggless female and soft male crabs collected from different crabs trading local depots and from shrimp farms. However the present study mainly focused on the fattening of female crabs in ponds. Table 3 is showing different grade of male and female crabs usually stock as seed for fattening.

\section{Pre stocking management}

Almost all fatteners (91\%) prepared their pond before stocking. However, only 34\%fatteners in Bagerhat district dried their pond before stocking. On the other hand, in Satkhira more than $83 \%$ and in Khulna more than 73\%fatteners dried their pond before stocking (Table 4). An average 94\%fatteners in those study areas applied lime at the rate of 0.5 to $1 \mathrm{~kg} \mathrm{decimal}^{-1}$. Significant variation was observed among the fatteners for drying their pond before stocking $(P<0.05)$. However, application of liming, fertilization and tilling did not vary significantly among those areas.

\section{Stocking density}

Stocking density of female crabs for fattening varied significantly between dry and wet season at $1 \%$ level of significance $(P$ value $<0.01$ ). From the research results, comparatively higher stocking density was found during dry season than wet season according to area (Table 5).

Significant variation in maintaining the stocking density was observed among the three areas during dry season. ( $P$ value is $<0.001$ ). During dry season, Total average stocking density during the dry season was about $3421.77 \pm 616.60 \mathrm{~kg} \mathrm{ha}^{-1} \mathrm{crop}^{-1}$ ranging from $1900 \mathrm{~kg} \mathrm{ha}^{-1} \mathrm{crop}^{-1}$ to $4879 \mathrm{~kg} \mathrm{ha}^{-1} \mathrm{crop}^{-1}$.

Average the stocking density for female crabs for fattening during wet season was about $3082.49 \pm 542.49$ (kg $\mathrm{ha}^{-1} \mathrm{crop}^{-1}$ ). Stocking density during wet season also varied significantly among the three areas at $5 \%$ level of significance.

\section{Post stocking management}

Post stocking management mainly involved regular monitoring, application of feed and periodic water exchange. Generally fatteners monitored their stocked crabs before applying feed. They found to separate the dead or diseased crabs from the stock during the production time and also checked the crabs for marketing through light checked observation.

\section{Feeding}

Commonly available small fishes, shrimp head and eel are used as crab feed. Fatteners mostly applied all of those feeds as raw during the fattening period. Usually fatteners in the three study areas were found to apply feed in every alternative day and some of them on daily basis at the rate of $5 \%$ to $10 \%$ of the body weight of the stocked crab. Distribution of the fatteners according to the feeding frequency is showed in Table 4. 
Table 1. Pond size by study area

\begin{tabular}{|c|c|c|c|c|}
\hline Pond Size & $\begin{array}{c}\text { Khulna } \\
n=50\end{array}$ & $\begin{array}{c}\text { Bagerhat } \\
n=50\end{array}$ & $\begin{array}{c}\text { Satkhira } \\
n=50\end{array}$ & $\begin{array}{c}\text { Total } \\
n=150\end{array}$ \\
\hline $\begin{array}{ll}\text { Average } & \text { size(in } \\
\text { hectare) } & \end{array}$ & $0.1 \pm 0.05$ & $0.1 \pm 0.06$ & $0.1 \pm 0.05$ & $0.1 \pm 0.05$ \\
\hline Maximum & 0.20 & 0.21 & 0.23 & 0.23 \\
\hline Minimum & 0.01 & 0.02 & 0.03 & 0.01 \\
\hline
\end{tabular}

$\mathrm{n}$ indicates sample size, Data is presented as mean \pm standard deviation

Table 2. Average water level an in crab fattening farms according to two seasons

\begin{tabular}{|lcc|}
\hline $\begin{array}{l}\text { Water level } \\
\text { (meter) }\end{array}$ & Dry season & Wet season \\
\hline Average & $0.65 \pm 0.27$ & $1.29 \pm 0.30$ \\
Maximum & 1.57 & 1.85 \\
Minimum & 0.23 & 0.51 \\
\hline
\end{tabular}

Table 3. Grade of mud crab used for fattening

\begin{tabular}{|llll|}
\hline \multirow{2}{*}{ Male } & Grade & Weight (gm) & Carapace \\
\cline { 2 - 4 } & PD-XXL & $>500$ & Soft \\
& PD-XL & $>400$ & Soft \\
& PD-L & $>300$ & Soft \\
& PD-M & $>250$ & Soft \\
& PD-SM & $<250$ & Soft \\
Female & Grade & Weight (gm) & Hepatopancreas \\
& KS1 & $>180$ & Partially developed \\
& KS2 & $>150$ & Poor \\
& KS3 & $<120$ & Poor \\
\hline
\end{tabular}

\section{Water exchange}

The crab fattening in Bangladesh is mostly traditional and fatteners do not maintain any water management practice like shrimp and prawn culture. When the water deteriorates severely they change the water. About 80\%fatteners in Satkhira district exchanged water during fattening period, while only $64 \%$ fatteners in Khulna and 48\%fatteners in Bagerhat districts exchanged water during their fattening time (Table 4).

\section{Production and production rate}

Production rate was calculated as the total amount of crabs harvested divided by the total amount of stocked following Rattanachote and Dangwatanakul (1992).

Production rate $=($ Weight harvested $/$ Weight stocked $) \times 100$

Table 6 is showing the average production and production rate during two seasons. Comparatively higher production was found during dry season than wet season. Production rate was also found higher during dry season in all study areas. Table 7 is showing the correlation between the production with the stocking density and the water exchange during dry and wet season. Significant correlation was observed between the stocking density and production (Table 7) during dry season. Production was also highly correlated with the water exchange (Table 7). Similar findings also revealed in wet season. Production during wet season found to be positively related with the stocking density and water exchange. Moreover, a significant positive correlation between stocking density and production also existed during wet season at $1 \%$ level of significance. 
Table 4. Distribution of crab fatteners according to the pre and post stocking management for mud crab fattening by area

\begin{tabular}{|c|c|c|c|c|}
\hline Pond management & $\begin{array}{l}\text { Khulna } \\
n=50\end{array}$ & $\begin{array}{l}\text { Bagerhat } \\
n=50\end{array}$ & $\begin{array}{l}\text { Satkhira } \\
n=50\end{array}$ & $\begin{array}{l}\text { Total } \\
n=150\end{array}$ \\
\hline \multicolumn{5}{|l|}{ Pond preparation } \\
\hline No pond preparation & $5(10)$ & $6(12)$ & $3(6)$ & $14(9.33)$ \\
\hline Pond preparation & $45(90)$ & $44(88)$ & $47(94)$ & $136(90.67)$ \\
\hline Total & $50(100)$ & $50(100)$ & $50(100)$ & $150(100)$ \\
\hline Drying & $\begin{array}{l}\text { Total } \\
n=45\end{array}$ & $\begin{array}{l}\text { Total } \\
n=44\end{array}$ & $\begin{array}{l}\text { Total } \\
n=47\end{array}$ & $\begin{array}{l}\text { Total } \\
n=136\end{array}$ \\
\hline No & $12(26.7)$ & $26(59.1)$ & $8(17)$ & $46(33.82)$ \\
\hline Yes & $33(73.3)$ & $18(40.9)$ & $39(83)$ & $90(66.18)$ \\
\hline Total & $45(100)$ & $44(100)$ & $47(100)$ & $136(100)$ \\
\hline \multicolumn{5}{|l|}{ Tilling } \\
\hline No & 13 (28.89) & $17(38.64)$ & 9 (19.15) & 39 (28.68) \\
\hline Yes & $32(71.11)$ & $27(61.36)$ & $38(80.85)$ & $97(71.32)$ \\
\hline Total & $45(100)$ & $44(100)$ & $47(100)$ & $136(100)$ \\
\hline \multicolumn{5}{|l|}{ Liming } \\
\hline No & $4(8.9)$ & $3(6.82)$ & $1(2)$ & $8(5.88)$ \\
\hline Yes & $41(91.1)$ & 41 (93.18) & $46(98)$ & $128(94.12)$ \\
\hline Total & $45(100)$ & $44(100)$ & $47(100)$ & $136(100)$ \\
\hline \multicolumn{5}{|l|}{$\begin{array}{l}\text { Fertilizer/chemical } \\
\text { application }\end{array}$} \\
\hline No & $27(60)$ & $23(52.27)$ & $25(48.9)$ & 75 (55.15) \\
\hline Yes & $18(40)$ & $21(47.73)$ & $22(51.1)$ & $61(44.85)$ \\
\hline Total & $45(100)$ & $44(100)$ & $47(100)$ & $136(100)$ \\
\hline Post stocking management & $\begin{array}{l}\text { Khulna } \\
n=50\end{array}$ & $\begin{array}{l}\text { Bagerhat } \\
n=50\end{array}$ & $\begin{array}{l}\text { Satkhira } \\
n=50\end{array}$ & $\begin{array}{l}\text { Total } \\
n=150\end{array}$ \\
\hline \multicolumn{5}{|l|}{ Feed Application } \\
\hline Daily & $16(32)$ & $24(48)$ & $27(54)$ & $67(45)$ \\
\hline Alternative & $34(68)$ & $26(52)$ & $23(46)$ & $83(55)$ \\
\hline Total & $50(100)$ & $50(100)$ & $50(100)$ & $150(100)$ \\
\hline \multicolumn{5}{|l|}{ Water Exchange } \\
\hline Yes & $32(64)$ & $24(48)$ & $40(80)$ & $96(64)$ \\
\hline No & $18(36)$ & $26(52)$ & $10(20)$ & $54(36)$ \\
\hline Total & $50(100)$ & $50(100)$ & $50(100)$ & $150(100)$ \\
\hline
\end{tabular}

$\mathrm{n}=$ sample size. Figures in brackets indicate percentages

Table 5. A comparison of stocking density $\left(\mathrm{kg} \mathrm{ha}^{-1} \mathrm{crop}^{-1}\right)$ between two seasons

\begin{tabular}{|lcc|}
\hline $\begin{array}{l}\text { Stocking density } \\
\text { (kg ha }^{-1} \text { crop }^{-1} \text { ) }\end{array}$ & Dry season & Wet season \\
\hline Average & $3421.77 \pm 616.60$ & $3082.49 \pm 542.49$ \\
Maximum & 4879 & 4591.67 \\
Minimum & 1900 & 1805 \\
\hline
\end{tabular}


Table 6. Average production $\left(\mathrm{kg} \mathrm{ha}^{-1} \mathrm{crop}^{-1}\right)$ and production rate by season

\begin{tabular}{|lll|}
\hline Production $\mathbf{~ k g ~ h a ~}^{-\mathbf{1}} \mathbf{c r o p}^{-\mathbf{1}}$ ) & Dry season & Wet season \\
\hline Average & $2961.83 \pm 566.42$ & $2424.04 \pm 508.01$ \\
Maximum & 4391.11 & 3546.43 \\
Minimum & 1615 & 1451.13 \\
Production rate (\%) & & \\
Average & $87 \pm 5$ & $78 \pm 7$ \\
Maximum & 96 & 89 \\
Minimum & 64 & 59 \\
\hline
\end{tabular}

$\mathrm{n}$ indicates sample size. Data is presented as mean \pm standard deviation.

Table 7. Correlation between production $\left(\mathrm{kg} \mathrm{ha}^{-1} \mathrm{crop}^{-1}\right)$ with the stocking density and water exchange facility according two seasons

\begin{tabular}{|lcc|}
\hline Water exchange & $\begin{array}{c}\text { Production dry } \\
\left(\mathrm{kg} \mathrm{ha}^{-1} \mathrm{crop}^{-1}\right)\end{array}$ & $\begin{array}{c}\text { Production wet } \\
\left(\mathrm{kg} \mathrm{ha}^{-1} \mathrm{crop}^{-1}\right)\end{array}$ \\
$\begin{array}{l}\text { Stocking density } \\
\left(\mathrm{kg} \mathrm{ha}^{-1} \mathrm{crop}^{-1}\right)\end{array}$ & $0.262^{\star \star}$ & $0.178^{\star}$ \\
& $0.955^{\star \star}$ & $0.897^{\star \star}$ \\
\hline
\end{tabular}

** Significant difference at $1 \%$ level, * Significant difference at $5 \%$ level

\section{Processing and marketing}

Fatteners check their stocked mud crabs everyday through light observation. The gravid fattened one is harvested for marketing. Fatteners generally sell the live crabs. It does not required any sophisticated processing like shrimp and prawn. Due to their cannibalistic nature, harvested crabs are tied with coarse twine to avoid the injury to human and physical damage cause by themselves, as well as reduce the mortality during transportation. Generally fatteners sell their crabs to the local man (collectors) or sometime directly to the depots. Mutual understanding is the major factor upon which the mode of payment was found to depend in case of purchasing and selling of mud crab in the research area. The payment was found to be $50 \%$ immediate or advance (Dadon) and $50 \%$ was found late.

\section{DISCUSSION}

Among four available mud crab species in the Indo-pacific region only the Scylla olivacea is being fattened in the southwest part of Bangladesh (Ahmed et al. 2005, Zafar, 2003). There is two crab fattening seasons in Bangladesh, one is the dry or peck season (October to May) and another one is lean season or wet season (June to September). Most of the fattening ponds are rectangular in shape with a common inlet and outlet made of PVC pipes for the water exchange facility during the culture period. Water level is important factor for crab fattening because fattening mainly based on the application of trash raw feed during production period. The present study the water level found to varied significantly during dry (5\% level of significance) and wet season (1\% level of significance) among the three study areas. The water level of their farm during dry season ranging from 1.57 to 0.23 meter and 1.85 to $0.51 \mathrm{~m}$ in wet season. Kamal et al. (2007) also reported the water level in mud crab farm of south region of Bangladesh ranging from 0.25 to 1.5 meter that is more or less similar with the findings of the present study.

Different types of pre-stocking management were observed among fatteners before stocking their crabs in their pond including drying, tilling, liming and fertilization application. However from the study, it reveals that about $6 \%$ interviewed fatteners did not apply lime it might be they did not understand the value of lime for increasing productivity through killing the water pathogens. 
Comparatively higher stocking density was found in dry season than wet season. The cause might be the availability of the crabs and high market price for the crabs in the market. According to crab fatteners the high price during the Chinese New Year and the availability of the crabs influencing them to stock more during dry season than wet season. Moreover, they also reported that usually they stocked less during wet season due to the unfavorable weather condition in wet season in the southwest part of Bangladesh (personal communication with fatteners).

Post-stocking management mainly involved feeding and daily monitoring of their stocked crabs. Most of the fatteners fed their stocked crab at 5 to $10 \%$ of the body weight. Before feeding they checked their crabs for marketing and also found to separate the diseased and dead one. To keep the water quality in a sustainable condition, most of the fatteners exchanged their water during the fattening time. Generally fatteners exchanged the water during the neap tide and spring tide. Ponds with water exchanged facility found to have higher production and production rate compared to the pond without water exchanged facility.

\section{CONCLUSION}

Mud crab fattening become popular in the southeast and southwest part of Bangladesh. But still this farming has some potential barriers that are working behind the production and development of this culture practice. Considering its prospects, mud crab fishery and farming can be new sources of income for coastal people in Bangladesh. Therefore, well developed co-operation and partnership among different stake holders in this sector is needed for the conservation and sustainable development of crab fishery.

\section{ACKNOWLEDGEMENT}

The author would like to express her gratefulness to all mud crab fatteners and the associate groups in the southwest part of Bangladesh that have given a lot of valuable information without which the study could not have been completed.

\section{REFERENCES}

1. Ahmed ATA Hossain MN and Iqbal M, 2005. Taxonomic status of the mud crab, Scylla olivacea (Herbst, 1796) in Bangladesh. Bangladesh Journal of Zoology, 33: 125-135.

2. Agabayani RF, 2001. Production economics and marketing of Mud crabs in the Philippines. Asian Fisheries Science, 14: 201-120.

3. Heasman MP and Fielder DR, 1983. Laboratory spawning and mass larval rearing of the mangrove crab Scylla serrata, from first zoea to first crab stage. Aquaculture, 34: 303-326.

4. Kamal D, Khanom M and Rheman S, 2007. Traditional practice of mud crab (Scylla olivacea) fattening in the south west region of Bangladesh. Khulna University Studies, 8: 269-285.

5. Khan MG and Alam MA 1992. The mud crab (Scylla serrata) fishery and its bio-economics in Bangladesh. In: Angell CA ed. Report of the seminar on the Mud Crab Culture and Trade. Surat Thani, Thailand, November 5-8, 1991. BOBP/REP/51. Madras, India: Bay of Bengal Programme pp. 29-40.

6. Keenan CP, Davie PJF and Mann DL, 1998. A revision of the genus Scylla De Haan, 1833 (Crustacea: Decapoda: Brachura: Portnidae). Raffles Bull. Zoology, 46: 217-245.

7. Rattanachote A and Dangwattanakul R, 1992. Mud crab (Scylla serrata Forskål) fattening in Surat Thani Province. In: Angell CA ed. Report of the seminar on the Mud Crab Culture and Trade. Surat Thani, Thailand, November 5-8, 1991. BOBP/REP/51. Madras, India: Bay of Bengal Programme, pp. 171-177.

8. Salam MA and Ross LG, 2000. Optimizing site selection for development of shrimp (Penaeusmonodon) and mud crab (Scyllaserrata) culture in South-western Bangladesh. GIS 2000 Conference Proceedings, March 13-16, Toronto, Canada.

9. Zafar M, 2003. Feasibility study on culture of mud crab (Scylla serrata) in the coastal area of Bangladesh. DFID (SUFER) Research Project. Institute of Marine Sciences, University of Chittagong. pp 7. 